\title{
Heidegger e a filosofia prática de Aristóteles
}

\author{
Jesús Adrian Escudero \\ tradução de Jasson da Silva Martins e \\ José Francisco dos Santos
}

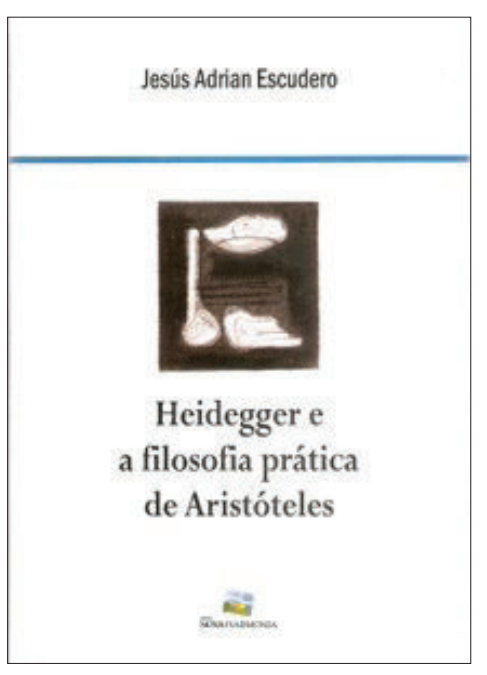

\section{por Roberto S. Kahlmeyer-Mertens}

Professor Doutor em Filosofia pelo IFCH-UERJ, Pós-Doutorando no PPGFIL

ESCUDERO, Jesús Adrian. Heidegger e a filosofia prática de Aristóteles. Trad. Jasson da Silva Martins; José Francisco dos Santos. São Leopoldo: Nova Harmonia, 2010. 
São conhecidos os influxos que as ideias de Aristóteles exercem sobre a posteridade. Prova de seu vigor filosófico, Aristóteles vive na obra de muitos filósofos contemporâneos, entre eles (talvez mais do que qualquer outro) o alemão Martin Heidegger (1889-1976). É expressiva a bibliografia dedicada à importância e influência de Aristóteles sobre Heidegger, ou às interpretações heideggerianas da filosofia aristotélica. Entre nomes já estabelecidos na disputa por este filão (Volpi, Brogan, Sadler, Berti...), vem se destacando, como resultado de décadas de trabalhos consagrados ao "Aristóteles de Heidegger", o nome do espanhol Jesús Adrian Escudero, autor de Heidegger e a filosofia prática de Aristóteles.

Em seu título, a obra em apreço acena com o tema da filosofia prática, todavia, contrariando uma interpretação mais imediata dessa indicação, o livro pouco tem a ver com uma axiologia de matriz aristotélica. Ao contrário, delimita o campo da filosofia do autor grego que esteve na pauta do jovem Heidegger em alguns de seus exercícios fenomenológicos e preleções didáticas; temática que já enseja o problema da vida fática, mas que, naqueles primeiros anos, ainda se detém no conceito de conhecimento. Assim, nos assegura Escudero:

As lições do semestre de 1921/22 Interpretações fenomenológicas de Aristóteles e o Informe Natorp de 1921/22, assim como as lições do semestre de verão de 1924 Conceitos fundamentais da filosofia aristotélica e, especialmente, as do semestre de inverno de 1924/25 Platão: O sofista oferecem uma panorâmica excelente e amplamente documentada de sua releitura em chave ontológica de passagens da Metafisica, da Física e, sobretudo da Ética a Nicômacos. A experiência direta do mundo, opina Heidegger, em sintonia com o conceito aristotélico de práxis, é a fonte de todo conhecimento. (p.10).

Embora esses trabalhos sejam proporcionalmente pouco conhecidos se comparados aos do final da década de 1920 e aos do início da de 30, muito do desenvolvimento filosófico de Heidegger deles dependeu, como o próprio filósofo frequentemente reconhecia.

Com base nesses dados, um olhar geral sobre o livro de Escudero nos permitiria indicar o quanto ele é revelador de traços decisivos da primeira filosofia de Heidegger, esforço de exposição que ainda nos permitiria entrever os interesses, nuances de formação e um pouco contexto histórico no qual o filósofo alemão propunha suas arro- 
jadas interpretações fenomenológicas dos gregos. A legitimidade desta avaliação, contudo, exigiria de nós uma apreciação dos conteúdos da obra. É o que teremos a seguir:

Conhecendo as obras de referências que tratam da redescoberta da filosofia de Aristóteles no século XX, Jesús Adrian Escudero, entre a introdução e o primeiro capítulo, não se dispersa em uma reconstrução do referido cenário de época partindo, logo, à evidenciação da importância que a filosofia de Aristóteles tem para determinada etapa do pensamento heideggeriano. Para tanto, nos apresenta um Heidegger leitor da tradição cristã e formado nas viçosas Ideen de Dilthey e Husserl, junto as quais, guardando suas particularidades, buscava um acesso originário à vida.

A intuição da gênese do pensamento hermenêutico-fenomenológico de Heidegger, entretanto, parece residir em momento anterior àquele que o filósofo apreende, com esses mestres, os rigores de seus métodos (respectivamente, o hermenêutico e o fenomenológico). Lembremos que é no ginásio, após a leitura da dissertação Sobre o múltiplo significado do ser em Aristóteles (1862) de Franz Brentano, que Heidegger se sente motivado a tratar daquela que ele entende ser a mais fundamental questão entre todas: a pergunta pelo sentido do ser. Este fato, somado a afirmação de Heidegger segundo a qual: "Meu Aristóteles é o de Brentano!" (possível de ser conferida em sua tese de doutoramento A doutrina do juízo no psicologismo, de 1913), obrigaria qualquer estudioso a esclarecer os laços de semelhança entre as duas interpretações. Assim Escudero o faz no segundo capítulo de seu estudo, esse intitulado: "Brentano e a pergunta pela unidade do ser".

Interpretado em consonância ao sentido do ser, e elemento de primeira ordem na ontologia fenomenológica de Heidegger, o conceito de verdade é objeto do terceiro capítulo de Heidegger e a filosofia prática de Aristóteles. Nesse tópico, é analisada a importância que a verdade, pensada originalmente por Heidegger, tem na economia de sua obra. Sem entrar nas nuanças do referido conceito, o que exigiria uma concentração pontual e desdobramentos estranhos ao proposto em seu breve estudo, Escudero é feliz ao apresentar como Heidegger (inicialmente beneficiário da compreensão de verdade como evidência, tal como encontrada no modelo fenomenológico husserliano) faz um gradativo deslocamento à compreensão de verdade como descerramento (alétheia), a luz da filosofia grega, especialmente a aristotélica.

Este exercício, com os muitos diálogos que fomenta, permite que o comentarista torne compreensível ao leitor a maneira com a qual Heidegger futuramente alicerçaria o conceito de verdade num solo ontológico-existencial; medida que, segundo Escudero, "abriu caminho para sua interpretação da história da metafísica". (p.46). 
Um detalhamento das muitas apropriações que Heidegger faz de Aristóteles é o que se vê no capítulo IV. Especialmente concentrado nas leituras heideggerianas da Ética a Nicômacos, consignadas nas preleções: Interpretações fenomenológicas de Aristóteles (1921/22) e Platão: O sofista (1924/25), tal tópico nos permite compreender como a descrição fenomenológica da existência e, por sua vez, da dinâmica utensiliar, efetuada por Heidegger em Ser e tempo (1927), nos reporta a conceitos aristotélicos.

Tendo em vista a filosofia prática do grego, Heidegger toma de empréstimo muitas concepções aristotélicas, entre elas: a poíesis, a téchne e a práxis. Para que sua interpretação ganhe inteireza, Heidegger ainda é obrigado a associar essas concepções a de phrónesis (destreza prática); assim, será como poíesis que Heidegger interpretará a ocupação cotidiana do ser-aí. Embora o verbo poieîn e o substantivo poíesis expressem tradicionalmente produção, Heidegger praticamente o assume como sinônimo de téchne que, como sabemos, é indicativo de uma atividade mais genérica. Heidegger, portanto, entenderá na chave poiesis-téchne qualquer atividade que incida sobre os entes. Por outro lado, o filósofo reserva o termo práxis para designar as atividades que determinam o próprio agente da ação, o que evidencia a dimensão prática (práxis) que o cuidado por si próprio (phónesis) possui. Estas considerações, produto da síntese desse capítulo que (nomeado "Da Ética a Nicômacos à ontologia da vida") é o mais substancial do livro, nos permite entender o quanto a filosofia prática de Aristóteles oferece subsídios para projetos filosóficos heideggerianos, como seria o caso da hermenêutica da facticidade, da destruição da história da metafísica e, sobretudo, da já aludida analítica existencial.

No último capítulo, podem ser observados temas pontuais da filosofia grega, como o movimento, a vida e a alma conjugadas na interface heideggeriana. A tônica do capítulo, entretanto, recai na questão do tempo, quando este se articula com a mobilidade constitutiva da existência do ser-aí humano. O saldo deste movimento - quase um reforço do que já se vira no anterior (desta vez com ênfase na questão do tempo) - é declarado ao fim, por seu autor, nos seguintes termos: "Com isso, fica aberto o caminho de Ser e tempo e a determinação do tempo como o horizonte de manifestação do ser". (p.112).

Heidegger e a filosofia prática de Aristóteles constitui uma introdução bastante satisfatória ao tema proposto, recomendável para aqueles que se iniciam nas pesquisas da seminal interação Heidegger-Aristóteles. A edição, estabelecida pela editora sulista Nova Harmonia, conta com tradução bem estabelecida e ainda permite que o leitor acesse a bibliografia usada por Escudero em seu trabalho, referência literária que constitui indicação certamente útil aos pesquisadores que desejarem um aprofundamento temático em novos títulos. 